NBER WORKING PAPER SERIES

\title{
THE EFFECT OF ADOLESCENT EXPERIENCE ON LABOR MARKET OUTCOMES: THE CASE OF HEIGHT
}

\author{
Nicola Persico \\ Andrew Postlewaite \\ Dan Silverman \\ Working Paper 10522 \\ http://www.nber.org/papers/w10522
NATIONAL BUREAU OF ECONOMIC RESEARCH 1050 Massachusetts Avenue
Cambridge, MA 02138
May 2004

This work was supported by National Science Foundation grants SES 0095768 and SES-0078870, which are gratefully acknowledged. The first author is grateful for an Alfred P. Sloan Foundation Research Fellowship. We thank Jere Behrman, Julie Cullen, Dan Hamermesh, Chris Peterson, Mark Rosenzweig, Gary Solon, and particularly Ken Wolpin for helpful conversations. We are grateful to the editor, Steve Levitt, and to an anonymous referee for comments and suggestions that greatly improved the paper. The views expressed herein are those of the author(s) and not necessarily those of the National Bureau of Economic Research.

(C)2004 by Nicola Persico, Andrew Postlewaite, and Dan Silverman. All rights reserved. Short sections of text, not to exceed two paragraphs, may be quoted without explicit permission provided that full credit, including (C) notice, is given to the source. 
The Effect of Adolescent Experience on Labor Market Outcomes: The Case of Height Nicola Persico, Andrew Postlewaite, and Dan Silverman

NBER Working Paper No. 10522

May 2004

JEL No. J7, J3, Z1

\section{$\underline{\text { ABSTRACT }}$}

Taller workers receive a wage premium. Net of differences in family background, the disparity is similar in magnitude to the race and gender gaps. We exploit variation in an individual's height over time to explore how height affects wages. Controlling for teen height essentially eliminates the effect of adult height on wages for white males. The teen height premium is not explained by differences in resources or endowments. The teen height premium is partly mediated through participation in high school sports and clubs. We estimate the monetary benefits of a medical treatment for children that increases height.

Nicola Persico

Department of Economics

University of Pennsylvania

3718 Locust Walk

Philadelphia, PA 19104

persico@econ.upenn.edu

Andrew Postlewaite

Department of Economics

University of Pennsylvania

3718 Locust Walk

Philadelphia, PA 19104

apostlew@econ.upenn.edu

Dan Silverman

Department of Economics

University of Michigan

611 Tappan Street

Ann Arbor, MI 48109

and NBER

dansilv@umich.edu 


\section{Introduction}

Labor market outcomes are likely to differ depending on a person's outward characteristics. These differences have motivated a large body of research focussed on the disparities across racial and gender groups. Beyond establishing the magnitude of the disparities, a goal of this research is to identify the channels through which the gaps develop. In this paper we take up the same research agenda with respect to height. We start by estimating the magnitude of the height premium, and find it comparable to those associated with race and gender. ${ }^{1}$ We then take advantage of a special feature of height relative to race and gender: height varies over time, so that a relatively tall 16year old may turn out to be a relatively short adult, and vice versa. This time-variation allows us to investigate the stage of development at which having the characteristic (in our case, being short) most strongly determines the wage disparity. We find that being relatively short through the teen years (as opposed to adulthood or early childhood) essentially determines the returns to height. We document that the beneficial effects of teen height are not complementary with any particular vocation path, broadly defined; instead, they manifest themselves in a higher level of achievement in all vocation categories. We point out some social activities that might be important channels for the emergence of the height premium. We use our estimates of the return to teen height to evaluate the monetary incentive to undertake a newly approved treatment that increases teen height, human growth hormone therapy. Finally, we show that teen height is predictably greater for sons of tall parents, meaning that there is an expected wage penalty incurred by the as-yet-unborn children of short parents.

Height is widely believed to be an important ingredient of professional and personal success. Popular books discuss the advantages of being tall. ${ }^{2}$ In the past 13 US presidential elections, the taller candidate has won 10 times (the most recent exception being George W. Bush) and, as shown in Figure 1, presidents tend to be distinctly taller than the average population. ${ }^{3}$

\footnotetext{
${ }^{1}$ While for methodological purposes we will compare our analysis with the literature on racial and gender discrimination, we do not imply that height discrimination, if the term were well-defined, is morally equivalent to racial or gender bias.

${ }^{2}$ See, for example, The Height of Your Life by Ralph Keyes: Little, Brown and Co. 1980.

${ }^{3}$ The height of Presidents is taken from http://www.uvm.edu/ tshepard/tall.html. The average height in the population is taken from Steckel (1995) and is the adult height of white males born in the US around the year in which the president was in office. Because average height is trending up, in any given year this measure most likely overestimates the average height of adults in the US population. The period 1850-1900 over which the height trend flattens is a possible exception.
} 


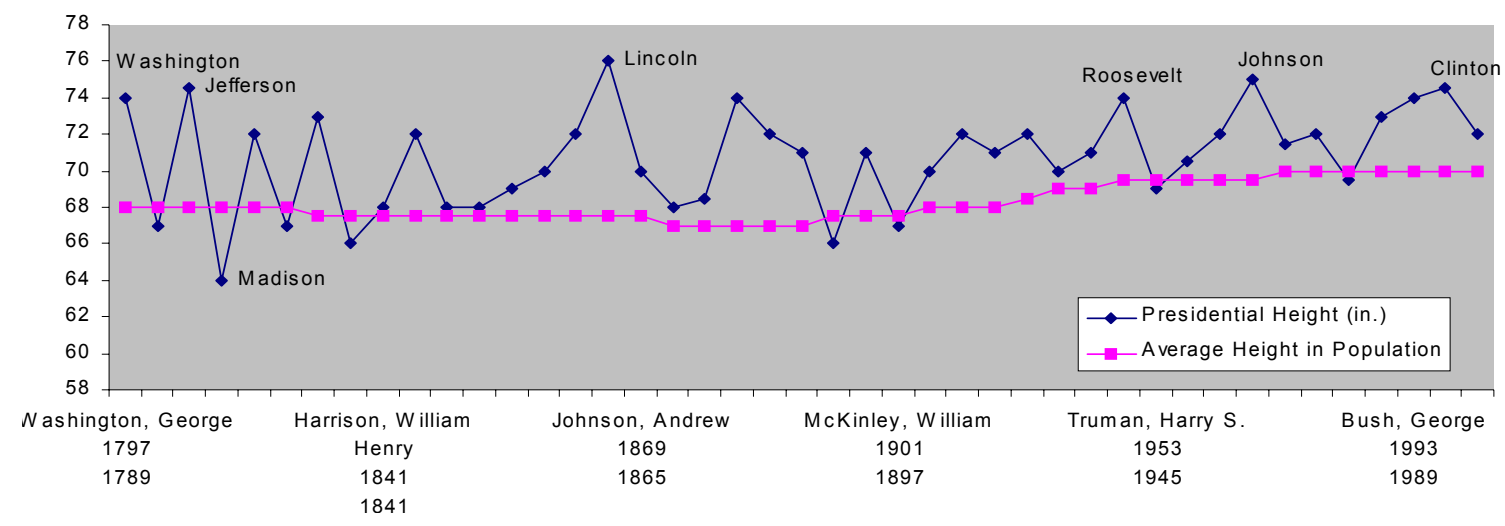

Figure 1: Height of US Presidents

There is an academic literature that investigates the possibility that labor markets reward height separate from ability. ${ }^{4}$ Following a standard approach that accounts for differences in productive characteristics and interprets the residual wage differential as a height premium, prior research has estimated that an additional inch of height is associated with a 0.025-5.5 percent increase in predicted wages. ${ }^{5}$ Taking into account the potential biases allowed by most of the previous literature, and using data from Britain's National Child Development Survey (NCDS) we find that among white British men every additional inch of adult height is associated with a 2.2 percent increase in wages. In a complementary analysis, drawing on data from the National Longitudinal Survey of Youth (NLSY) we find that among adult white males in the US, every additional inch of height as an adult is associated with a 1.8 percent increase in wages. As the interquartile range of adult heights spans 3.5 to 5 inches in our data (in Britain

\footnotetext{
${ }^{4}$ This research is found mainly in sociology and psychology. For a review of the evidence from sociology and psychology see Martel and Biller (1987). A more recent example from this literature is Frieze et al. (1990). This evidence is not only drawn from less developed economies where physical size may be an important determinant of productivity (see Steckel (1995) for a review of the connection between height and standard of living).

${ }^{5}$ Sargent and Blanchflower (1994) estimate the effect on age-23 wages of height measured at various ages, for the NCDS cohort born in 1958. They estimate that every additional 10 centimeters in height at age 16 (23) is associated with 2.7 (3.3) percent increase in wages at age 23. Using the NLSY data, Loh (1993) regresses wages on adult height and estimates that workers who are below-average height as adults earn 4\%-6\% less than above-average workers. Berhman and Rosenzweig (2001) use the variation in height between monozygotic female twins, and estimate that every additional inch of height is associated with a 3.5-5.5 percent increase in women's wages.
} 
and the US, respectively), the tallest quarter of the population has a median wage that is more than 13 percent higher than that of the shortest quarter. The impact of this height wage disparity is comparable to those associated with characteristics such as race or gender. ${ }^{6}$

Beyond estimating the magnitude of the height premium, our primary focus is to investigate its roots. Several plausible theories have been proposed for why markets might treat shorter people differently. A leading theory in social psychology describes the interpersonal dominance derived from height. According to this theory, short people are stigmatized by others, perceived less positively, and thus placed at a disadvantage in negotiating interpersonal dealings. ${ }^{7}$ Evolutionary selection may also explain the disadvantages of being shorter than competitors. As the human species evolved, to the extent that size provided a direct advantage in the competition for resources, a preference for associating with tall people might have been naturally selected. In addition, greater height may have signaled good health throughout the development process, and therefore a genetic makeup robust to illness and deprivation. To the degree that this signal translated into a preference for taller mates, this may provide an explanation for why, other things equal, shorter people may be viewed as less appealing. These theories are designed to explain a 'taste' for height among employers. A final theory emphasizes self-esteem by placing the roots of the height premium in a superior conception of self that is achieved through a comparison with a socially-determined notion of ideal height. A greater self-image leads to higher achievement through a variety of channels, including perseverance and interpersonal skills.

The theories presented above are designed to account for the adverse consequences of a current lack of height. Of course, the fact that we observe a height wage premium does not imply that shorter workers are penalized for their current stature. There may be another characteristic, correlated with current height and valuable to employers that is in fact acquired at some pre-market stage. We can think of this characteristic as a form of human capital, a set of skills that is accumulated at earlier stages of development. If this characteristic were unobservable to the researcher, the lower wages of shorter people would be incorrectly ascribed to their lack of height, instead of to their lack of human capital. For example, short children, if stigmatized because

\footnotetext{
${ }^{6}$ Correcting for differences in family background and region of residence, we estimate the blackwhite wage gap to be approximately $15 \%$ among full time male workers in the NLSY. Similar analysis indicates that the male-female wage gap is approximately $20 \%$ among white full-time workers in both the NCDS and NLSY.

${ }^{7}$ See, Martel and Biller (1987) and Frieze, et al. (1990).
} 
of their stature, might find it more difficult to develop interpersonal skills, positive self-conception, or might simply be excluded from participation in groups that foster the development of skills. The mechanisms that generate the disadvantage of short people in acquiring human capital could include any of the channels presented above (interpersonal dominance, self-image, etc.) which may have an impact at any early stage of development. An alternative theory, statistical discrimination, might predict that children who forecast being short adults invest less in human capital because the returns to human capital are smaller for short adults; a rational individual will invest less in assets that provide lower personal return.

Finally, we might entertain a theory that pushes back the source of the height premium to birth: taller people might be endowed to a greater degree with some favorable characteristics. These characteristics could be family resources which raise a person's productivity, or other characteristics such as intellectual stamina or work energy, that are directly productive characteristics independent of external factors.

Distinguishing among these theories is important for understanding the channels through which outward characteristics affect market outcomes. The magnitude of the height premium alone makes it important to investigate these theories. In addition, understanding the ways in which height affects income may shed light on other labor market disparities such as the race and gender gaps. In the case of the height, it is possible to make progress on tests of the relative importance of these theories. Alone among common bases of labor market disparities, height is impermanent. Relative stature often changes as an individual grows to his or her full adult height. Participants in the NCDS were measured by physicians at ages 7,11, 16, and 33, and self-reported height at age 23. Respondents to the NLSY provided self-reported measures of height in 1981, 1982 and 1985. Of particular interest for the present study is that in each of these samples, among those who were relatively short when young, many grew to become average height or even tall adults. These changes in relative stature provide an opportunity to understand better the sources of the height premium.

We show that two adults of the same age and height who were different heights at age 16 are treated differently on the labor market: the person who was taller as a teen earns more. In fact, the preponderance of the disadvantage experienced by shorter adults on the labor market can be explained by the fact that, on average, these adults were also shorter at age 16. This finding suggests that a large fraction of the disparity is not due to a taste for tall adult workers, or to any employer's preference for height when young (which the employer presumably cannot observe); rather, the disparity must reflect a characteristic correlated with height when young. This observation 
leads our investigation away from a theory of the labor market's taste for height, and toward an analysis of the nature of the unobservable characteristic.

We show that the teen height premium does not much diminish when we control for variables such as family resources, good health, and native intelligence. Using the fact that NCDS measures height at ages 7 and 11 in addition to 16 and 33 we are able to parse the contribution to the height premium of being tall at different ages. When we regress wages on height measured at ages $7,11,16$, and 33 we find that only age-16 height has either an economically or statistically significant coefficient. Among the different heights, therefore, height at age 16 uniquely influences future wages. The negligible role played by height prior to age 16 (together with other supporting evidence) suggests that the height premium is not simply a premium to early development at any age.

The wealth of data provided by the NLSY allows an analysis of the channels through which teen height influences later wages. In the US data, those who were relatively short when young were less likely to participate in social activities associated with the accumulation of productive skills and attributes. ${ }^{8}$ About half of the wage differential can be accounted for by variation in participation in school-sponsored non-academic activities (such as athletics and clubs), and a smaller fraction of it can be explained by greater levels of schooling. We interpret these findings as evidence of the effects of social factors on the development of human capital and the distribution of economic outcomes. Viewed in this light, our findings suggest that social effects during adolescence, rather than contemporaneous labor market discrimination or correlation with productive attributes may be at the root of the disparity in wages across heights.

In our effort to better understand the channels through which teen height affects wages, we establish that the height premium is not reflected in an observably different choice of occupations, broadly defined. Thus, the height premium is reflected in a higher level of achievement within the same vocation category, broadly defined. Overall, the beneficial effects of teen height seem to accrue across the board, as a sort of all-purpose resource.

Finally, we use our estimates of the teen height premium to calculate the monetary return to an investment in teen height, i.e., a treatment with human growth hormone

\footnotetext{
${ }^{8}$ Examples of human capital that might be acquired through such activities include skills of interpersonal negotiation, social adaptablity, and motivation. Productive attributes that are often ascribed to participation in extra-curricular activities include self-esteem and self-discipline. See Heckman (2000) for a complete discussion of the importance of these 'non-cognitive' skills, and their development by social institutions.
} 
(HGH). From our viewpoint, the HGH treatment represents an indirect investment in human/interpersonal capital of the type that we have suggested. Because the treatment was not available to the individuals in our data set, we have an opportunity to perform a cost-benefit analysis of an investment in this type of human capital. Since the return to investment is a percentage of adult wages, taking into account the cost of treatment we find that males with expected average annual earnings exceeding $\$ 100,000$ have a monetary incentive to undertake the HGH treatment.

\section{Data}

Our two main data sources are the NCDS and the 1979 youth cohort of the NLSY. The findings from the NLSY closely parallel those in the NCDS. We draw attention to the aspects in which the results from the US and Britain are substantially different, and where some distinctive features of the each data set provide additional insight.

The NCDS began as a perinatal mortality study of all the children born in England, Scotland and Wales during the week beginning March 3, 1958. Seven years later, an attempt (sweep) was made to recontact all of the children who survived infancy. Similar sweeps were made again when the children were ages 11, 16, 23 and 33. At age 33, $11,407(66 \%)$ of the original 17,414 children were recontacted and at least partially surveyed. ${ }^{9}$ The NLSY began in 1979 with 12,686 men and women ages 14-21, and has interviewed this cohort every year until 1994, and every other year since then. Respondents to the NLSY were first asked to report their height in 1981, when they were ages 16-23, and most recently in 1985 when they were ages $20-27$. We will refer to height measured in 1985 as adult height.

To avoid confounding the effects of race, gender and height discrimination we focus our attention primarily on white males. In Britain this implies excluding the small number of native-born non-whites; we also exclude those participants in the NCDS who immigrated to Britain after 1958. In the US we focus on the 2,063 white, non-Hispanic males for whom there exists both adequate height data, and other information. ${ }^{10}$

Table 1 presents summary statistics of the height measures from our primary data sets, along with statistics from an unrelated survey of measured height in the US.

\footnotetext{
${ }^{9}$ Selection analysis indicates that those from Scotland and the Northwest of England, and those with lower reading test scores at age 7 were less likely to respond to the fifth sweep. Elias and Blanchflower (1988) find similar results with respect to the fourth sweep.

${ }^{10}$ Our interest in adult wages also leads us to exclude the entire NLSY oversample of poor whites who were dropped from the survey after 1990.
} 
We note a few features of the data. First, even when attention is restricted to white men, there is substantial cross-sectional variation in adult height. The data include respondents as short as 60 inches and as tall as 83 inches. The interquartile range spans 3.5 inches (NCDS) and 5 inches (NLSY). Second, while in the NCDS the average change in height between ages 16 and 33 (2.5 inches) represents a substantial fraction of total variation in adult height, in the NLSY the variation in height over time is limited by the fact that respondents were 16 or older when first measured, with more than half being older than $18{ }^{11}$ On average, the NLSY sample grew just 0.28 inches between 1981 and 1985. Of the NLSY respondents, 618 (30\%) reported growth of at least one inch over the period; among those who grew, the average change was 1.68 inches. Nevertheless, as our later analysis shows, this variation in height over time is adequate to provide reasonably precise estimates of the relationship between youth height and adult outcomes, conditional on adult height.

A potentially important limitation of the NLSY data is that height is self-reported to the nearest inch, which raises the issue of measurement error. To illustrate, we note that among our white male subsample, 315 (15.2\%) respondents report a height in 1985 that is strictly less than what they reported in 1981, and $75(3.6 \%)$ report a decline in height of more than one inch. ${ }^{12}$ By itself, the presence of classical measurement error may strengthen our results, as the error would be expected to bias the coefficients of interest towards zero. Nevertheless, we would like a gauge for the accuracy of self reporting. By one measure the height data recorded in the NLSY appear reasonably accurate. The distribution of the NLSY's self-reported heights is quite similar to that of a national survey of carefully measured heights completed in 1980; with the distribution in the NLSY shifted slightly to the right, and having a fatter right tail. ${ }^{13}$

In contrast, in each sweep of the NCDS except for the age-23 sweep, height is measured by a physician. The advantages of the earlier and more accurate height measures in the NCDS are clear. Among the 1,772 white men for whom there exists sufficient data, the average growth between ages 16 and 33 is 2.54 inches, and just 44

\footnotetext{
${ }^{11} \mathrm{It}$ is estimated that in the US adult height is reached at a median age of 21.2 years for males, with a median growth after age 16 of slightly less than 1 inch (Roche 1992, pp. 104-5).

${ }^{12}$ Not all those who report a decrease in height need be in error. Damon, Stoudt, and McFarland (1966) p. 50 reports that adults shrink by an average of 0.95 inches over the course of a day.

${ }^{13}$ The National Health and Nutrition Examination Survey conducted by the National Center for Health Statistics between 1976 and 1980 measured standing height against a calibrated bar and used a camera to standardize recording. In this survey, the average measured height for white males ages 1824 was 69.8 inches, with a standard deviation of 2.8 inches. See National Center for Health Statistics (1987), Table 13. The comparable figures in our subsample of the NLSY are 70.41, and 2.85.
} 
(2.5\%) report negative growth over this period. ${ }^{14}$ We will use age-33 height as our measure of adult height, to eliminate any bias induced by self-reporting. The presence of another measure of adult height - self-reported at age 23-is useful because it allows us to gauge the impact of the bias induced by self-reporting of heights. In the NCDS, at least, this bias is negligible: all the coefficients in this paper are almost identical when age-33 height is replaced by age-23 height.

\section{Evidence of the Height Premium}

Our first task is to examine whether in our data sets, consistent with the literature, there are sizable associations between height on wages. There are some important aspects in which our investigation differs from previous studies. Unlike much of the prior research, we estimate the regression equations separately by race and gender, and focus on the results for white, non-Hispanic males. As noted above, estimating the equations separately avoids confounding the effects of race, gender and height discrimination; moreover this approach allows all of the coefficients to differ by race and gender. In addition, unlike most prior studies, we are able to measure wages at a relatively advanced age (31-38) and thus capture the cumulative effects of differences in height. Finally, our approach to estimating the effect of height takes care to avoid controlling for variables such as education, work experience, and occupation that are endogenous, i.e. choice variables that may be influenced by height. This approach is consistent with the strategy taken by Neal and Johnson (1996) who, along with Heckman (1998), provide detailed arguments against accounting for differences in decision variables when estimating the effect of labor market discrimination.

To begin our assessment of the relationship between height and wages, Table 2 compares summary statistics of the white male subsample by above- and below-median adult height. For the adult outcomes in the NCDS we consider wages at age 33; in the NLSY we consider the data from 1996 when respondents were 31 to 38 years old. The statistics on adult wages summarize only the data for full time workers. ${ }^{15}$ Comparing

\footnotetext{
${ }^{14}$ Among the shrinkers, 19 respondents report shrinking by an inch or more during this period. The NCDS has disadvantages as well. For large fractions of those successfully contacted in the later sweeps, data from their earlier sweeps (including height measures) are incomplete.

${ }^{15}$ In the NCDS, wages are defined as gross pay per reporting period divided by usual hours worked during reporting period. (The reporting period varies depending on how often the respondent is paid.) In the NLSY wages are defined as annual income from wages, salaries and tips, divided by annual hours worked. Full time workers are identified as those who worked more than 1,000 hours in the previous year. The results discussed here and elsewhere in the paper are qualitatively unchanged
} 
mean log of wages, we find that the average wage of shorter males is 11 percent lower than that of the taller group in the NCDS and 10 percent lower in the NLSY.

Importantly, these shorter and taller males come from family backgrounds that are also different. In particular, Table 2 shows that compared with their taller counterparts, shorter males, on average, come from larger families with less educated parents who were less likely to have worked in skilled or professional occupations. ${ }^{16}$ Thus, an immediate concern is that the disparities in the average adult outcomes of taller and shorter males reflect these differences in family background rather than any form of height premium. Growing up in families with less human and financial capital, shorter than average men may be placed at a disadvantage in the labor market for reasons that have nothing to do with their lack of height.

To account for the influence of these systematic differences in family background, Table 3 presents OLS estimates of the effect of height on wages holding constant a number of family characteristics. ${ }^{17}$ Results from the NCDS are presented along side those from the NLSY. In Columns 1 and 5, the first, simple regression of log wages on height, age, and region of residence ${ }^{18}$ indicates that every additional inch of adult height is associated with an increase in wages of $2.7 \%$ percent (or an average of approximately $£ 422$ (\$756) in 1991 full-time equivalent annual earnings) in the NCDS, and 2.5 percent (or an average of $\$ 820$ in 1996 full-time equivalent annual earnings) in the NLSY. In Columns 2 and 6, after controlling for family characteristics including parents' education and occupation status, and number of siblings, the coefficient on adult height is reduced to 2.2 percent in the NCDS and 1.8 percent in the NLSY. ${ }^{19}$

hours worked. Full time workers are identified as those who worked more than 1,000 hours in the previous year. The results discussed here and elsewhere in the paper are qualitatively unchanged when other definitions of full time work are used.

${ }^{16}$ The mothers of shorter men in the NCDS are an exception.

${ }^{17}$ Here, as in our subsequent regression analyses, we assume that, conditional on other observables, an individual's heights at various ages are exogenously given. This assumption precludes, for example, a model in which, conditional on other observables, height at various ages is determined in part by parents' unobservable investment decisions that also contribute directly to adult productivity and thus to adult wages.

${ }^{18}$ There are small, but statistically significant differences in the distribution of heights across regions. We find, for example, that males from Scotland are on average 0.5 inches shorter than those from the East or the North Midlands of England. In the US, white males in the Northeast are, on average, 0.45 inches shorter than their counterparts in Northcentral states, and 0.59 inches shorter than in the Southern states.

${ }^{19}$ We also consider whether differences in measures of school quality such as student-teacher ratio, disadvantaged student ratio, dropout rate and teacher turnover rate may explain more of the height wage premium. In each data set introducing these controls for school quality leaves the estimated 
Although the estimated coefficients on height are somewhat reduced after accounting for differences in some external resources, the reduction is minor especially when compared with the analysis of Neal and Johnson (1996), who find that family and school variables may account for a large fraction of the racial wage gap. In our analysis, the fact that taller people tend to come from somewhat more advantaged families does not explain a large part of the height premium.

\section{It's All in Teen Height}

The fact that shorter people are penalized on the labor market does not imply they are penalized for being short. We now argue that much of the wage disadvantage experienced by shorter people can be explained by a characteristic other than adult height, namely height in adolescence. This finding casts substantial doubt on the relevance of a taste for height as an explanation for the observed wage premium.

\subsection{Irrelevance of Adult and Pre-teen Heights}

Adult height predicts wages only insofar as it is correlated with teen height. The evidence for this claim comes both from the NCDS and the NLSY. (For height when old and young, in the NCDS we use age-33 and age-16 height, in the NLSY height reported in 1985 and 1981.) Consider a random sample of 33 year-old males all of the same height. Among this group, individuals will have been more or less tall at age 16. More specifically, some will not have grown at all in the intervening years, while others may have grown several inches to achieve this adult height. Conditional on adult height, we find a sizable (and statistically significant) difference between the wages of late and early maturers - a 'teen-height premium.' In fact, of the total effect that might be ascribed to adult height discrimination, nearly all can be attributed to the fact that adults who are relatively tall at age 33 tend to be relatively tall at age 16.

A regression analysis is reported in Table 3. Each specification takes the following form:

$$
w_{i}=\alpha_{0}+\alpha_{1} H_{i, a d u l t}+\alpha_{2} H_{i, y o u t h}+\boldsymbol{\alpha} \mathbf{X}_{i}+u_{i}
$$

effect of adult height on adult wages essentially unchanged. See Persico, Postlewaite and Silverman (2003) for details. 
where:

$$
\begin{aligned}
w_{i} & =i \text { 's adult wage } \\
H_{i, \text { adult }} & =\text { adult height } \\
H_{i, \text { youth }} & =\text { youth height } \\
\mathbf{X}_{i} & =\text { a vector of other covariates } \\
u_{i} & =\text { an error term }
\end{aligned}
$$

In the first, basic specification, (Table 3, Columns 3 and 7) we regress adult wages on adult height, youth height, age, and region. In this basic specification we find that, conditional on adult height, every additional inch of height when young, is associated with a $2.6 \%$ increase in adult wages in Britain, and a $2.7 \%$ increase in the US. Importantly, when we control for youth height, the estimated effect of adult height on wages is nearly zero. The point estimate suggests that conditional on youth height, any additional adult height is associated with a statistically insignificant $0.4 \%$ increase in adult wages in the British data. In the US data the estimated coefficient on adult height is a statistically insignificant $0.2 \%$.

As in Section 3 concerning the analysis of adult height alone, we move on to account for a possible relationship between height and aspects of family background. ${ }^{20}$ Adding controls for family characteristics (Columns 4 and 8) changes the estimates slightly. Accounting for differences in family background we find that, conditional on adult height, every additional inch of age- 16 height is associated with a somewhat diminished, but still highly significant $2.1 \%$ increase in adult wages in Britain, and a $2.6 \%$ increase in the US. Controlling for the effect of youth height, we estimate that adult height is associated with a $0.5 \%$ but statistically insignificant increase in adult wages in Britain. In the US, the estimated effect of adult height on wages is $-0.4 \%$ but not statistically different from zero. Thus, the finding that pre-adult height, rather than adult height itself, determines the wage premium is robust to the introduction of controls for region and family background. ${ }^{21}$

\footnotetext{
${ }^{20}$ It may be argued that, to capture the gross effect of teen height on adult wages, it is appropriate to condition on the teen's stock of human capital. One argument for such a specification is that, conditional on adult height and family resources, investments in human capital that are positively correlated with later wages are also positively correlated with teen height. Observe, however, that to the extent that these investments are the result of greater stature, conditioning on teen human capital would lead to an underestimate of the gross effect of teen height on adult wages. Consistent with this interpretation, our analysis indicates that while pre-teen investments in human capital are unrelated to the teen height premium, post-teen investments may be. See Tables 6 and 7 below.

${ }^{21}$ In the relevant samples, introducing controls for school quality leaves unchanged the estimated
} 
The data from the NCDS also afford an opportunity to parse further the height premium according to the age at which relatively high stature is attained. Respondents to the NCDS were also measured at ages 7 and 11, allowing us to consider the extent to which height at these ages contributes to the height premium. It is clear that each of these heights, if considered on its own (without conditioning on other heights), will appear to carry a wage premium simply because of the positive correlation between heights at all ages. To determine the extent to which teen height proxies for preteen heights, we examine how the estimated contribution of teen height is changed when we introduce earlier heights. Table 4 considers only those respondents for whom there exists data on age 33, 16, 11 and 7 heights. The basic estimation (Column 1) regresses log of age-33 wages on age-33 height, age-16 height, family background, region. Column 2 adds controls for both pre-teen heights. Comparing the results in Columns 1 and 2 we find first that age- 11 and 7 heights have no appreciable effect on adult wages. Conditional on all other heights, the estimated effect of an increase in either age-11 or age- 7 height is nearly zero. In addition, introducing these controls for earlier height leaves the estimated effects of both age-33 and age-16 height essentially unchanged. Among all recorded heights, only age-16 height is estimated to have an economically large and statistically significant effect on adult wages; no other height makes an appreciable contribution to the height premium.

Since the effect of adult and pre-teen heights on wages, conditional on teen height, is nearly zero, this analysis indicates that the adult height-wage disparity is not due to a taste for tall workers. Rather, the different outcomes for taller and shorter workers appear to reflect a characteristic correlated with teen height.

\section{Explaining the Teen-Height Premium}

\subsection{Not an Effect of Observable External Resources}

As shown in Section 4.1, differences in family and school resources explain little of the disparity between tall and short adults. The coefficient on teen height (adult and/or

effect of an additional inch of youth height in the NCDS, and reduces it from $2.7 \%$ to $2.5 \%$ in the NLSY. Our results in each data set are also qualitatively and quantitatively robust to the exclusion of outliers in height, growth and wages, and to the inclusion of part-time workers. Moreover, we experimented with several non-linear specifications and found that the primacy of teen height in explaining the height premium is not an artifact of the linear specification. See Persico, Postlewaite and Silverman (2003) for details. 
youth) was little changed in both the British and the US data when we controlled for family and school background characteristics, and our finding of a 1.9-2.6\% per-inch teen height premium is net of family background characteristics. The conclusion that the height premium is not driven by family background characteristics draws additional support from the analysis of Behrman and Rosenzweig (2001), who find evidence of a sizable wage premium between female twins of varying heights.

One may argue that the robustness of the teen height premium to controlling for resources is due to the necessarily imperfect quality of our measure of resources. According to this argument, teen height is a better indicator than our imperfect measure of resources of some productive unobservable which is directly related to resources. Our measures of resources, however, perform quite well in predicting performance on achievement tests. For example, our measures of family background can explain at least 29 percent of the variation in AFQT scores.

In addition, to the extent that external resources are correlated with height at all ages, if resources were driving the height premium then we should expect heights at all ages to be positively associated with wages. Since only teen height seems to matter in the data, the only remaining possibility is that heights at various ages may be proxying for the same unobservable, productive resources but teen height is much better correlated with these unobservable resources. In that case we might obtain the estimates we have, but our interpretation would be misleading. Plausible candidates for unobservable productive factors may be summarized by the child's home environment. Home factors may contribute to health, cognitive development, and other forms of human capital. One way to assess the influence of such home factors in determining the estimated teen height premium is to test whether teen height is systematically a better predictor than all other heights of observable endowments that are plausibly correlated with productive home factors. ${ }^{22}$ If teen height were, in fact, a better predictor of observable home endowments, we would have more reason to be concerned about the influence on our estimates of correlation between teen height and omitted productive home factors. Appendix A presents the results from regressions of various endowments on heights at different ages. Generally, we find that each of the heights is only very weakly associated with these observable endowments, and we find no evidence that teen height is a systematically better predictor of these endowments.

\footnotetext{
${ }^{22}$ We are grateful to Esther Duflo for suggesting this procedure.
} 


\subsection{Not an Effect of Unobservable, Intergenerationally Cor- related Resources}

The previous subsection has ruled out the possibility that the teen height premium reflects a correlation between teen height and certain measurable resources. In addition, the previous subsection casts doubt on the possibility that the teen height premium reflects unobserved resources plausibly correlated with observable endowments. In this section we provide additional evidence that the teen height premium is not merely a reflection of omitted, unobserved resources, such as the wealth of the family, the amount of social connections, etc. While controlling for such unobservable variables is impossible in this context, inference may still be drawn about their effects as long as these variables are positively correlated across generations. Suppose, for example, our concern was that well-connected, high social class individuals are more likely to be tall as teens. Since well-connnectedness is presumably positively correlated across generations, controlling for the father's teen height would diminish the effect of teen height on wages. More generally, if controlling for the father's teen height reduces the size of the son's teen height premium, we can infer that the teen height premium partly reflects the omission of unobserved resources that are correlated across generations. ${ }^{23}$ The NCDS allows us to implement a variant of this empirical strategy because that data set contains a measure of the father's adult height, a relatively good proxy for the father's teen height. Our strategy will be to assess the effect on the estimated teen height premium of introducing father's adult height as a control. Restricting attention to those with information on father's height in Columns 3 and 4 of Table 4, we find that the effect of controlling for father's height is negligible. We conclude that there is no evidence of an unobservable resource that can account for the teen height premium and is correlated across generations.

\subsection{Not a Proxy for Good Health or Weight}

Another potential explanation for the teen height premium is that teen height proxies for health problems experienced before or during adolescence that inflict lasting damage and depress adult wages. Indirect evidence against this hypothesis is provided by the findings of Section 4.1, which indicate that height before adolescence does not account for the teen height premium. Direct evidence is available, to varying degrees, both in the NCDS and in the NLSY. These data sets allow us to investigate the importance of

\footnotetext{
${ }^{23}$ See Persico, Postlewaite and Silverman (2003) for a rigorous argument.
} 
health in explaining the teen height premium.

In the NCDS, the physical exams that provide our height measures also provide detailed information on the respondents' health status. To the extent that the teen height premium is attributable to better health among the tall, conditioning on this health information would be expected to diminish the coefficient on age-16 height. Table 5 presents results from regressions in which we add to our set of explanatory variables the number of health conditions reported by the physician in the age 7 and age 16 exams. $^{24}$ Consistent with the idea that poor child or adolescent health has a lasting impact, these measures of health are have economically important, negative associations with adult wages. However, introducing these measures does nothing to reduce the estimated teen-height premium.

The NLSY lacks detailed health measures until the respondents reach their 40's. In every survey year since 1979, however, respondents were asked whether they have a health condition that limits the kind or amount of work that they can do. We control for these measures in columns 5-8 of Table 5. The results indicate that the kind of work health limitation has an economically important and statistically significant negative association with adult wages. The amount of work limitation measure has a positive point estimate, but is not statistically distinguishable from zero. In either case, the inclusion of these health measures does not appreciably affect the size of the teen height premium. In sum, controlling directly for health conditions leaves the estimate of the teen height premium essentially unchanged.

A complementary approach is pursued in Appendix A where we regress health measures on heights at different ages (see Table A1). Generally, we find that each of the heights is only very weakly associated with these health measures, and we find no evidence that teen height is a systematically better predictor of the health measures positively associated with wages. We therefore conclude that, with respect to the height wage premium, teen height is not merely proxying for good health.

Another possibility is that teen height is proxying for weight. If, for example, short teens were more likely to be overweight and being overweight as a teen decreased expected adult wages, then we might incorrectly attribute to height some adverse effects that are in fact due to weight. Weight, however, is a choice variable to a greater degree than, for instance, external resources or even good health, and so we must be especially careful in interpreting any regression result. In Table 5, Columns 5 and 9 we regress adult wages on height alone (plus our usual controls), and then we look at how the

\footnotetext{
${ }^{24}$ This methodology follows Case, Fertig and Paxson (2003). See notes in Table 5 for a detailed description of the health conditions.
} 
coefficient on height changes as we introduce weight in the regression in Columns 6 and 10. To the extent that weight is not a choice variable for the individual, a decrease in the coefficient on teen height would indicate that teen height is proxying for weight. To the extent that weight is a choice variable, a decrease in the coefficient on teen height would suggest that part of the effect of teen height on adult wages is channeled through weight. We find that adding the controls for weight leaves our estimates of the adult and teen height premia essentially unchanged. We conclude that the teen height premium is largely independent of weight.

\subsection{Not a Premium to Native Intelligence or Early Cognitive Development}

Suppose that height were proxying for native intelligence; given the pattern we observe where age-16 height alone among heights at all ages explains wages, the productive components of native intelligence must be most strongly correlated with age-16 height. Although this hypothesis seems peculiar, we can use the NCDS to investigate it by conditioning on the score of a test of academic achievement taken at age 7 . Insofar as academic achievement at age 7 measures native intelligence, conditioning on the test score ought to reduce the coefficient on age- 16 height. Table 6 presents the effect of introducing age- 7 test scores on the coefficient for age-16 height. Note that all of these estimates account for differences in family backgrounds, so the test scores do not proxy for these characteristics.

Columns 1 and 2 of Table 6 restrict attention to those respondents to the NCDS with information on height ages 16 and 33, and test scores at age 7 . Consistent with the notion that they capture native intelligence, the test scores contribute importantly on their own to explaining adult wages. Each test score is associated with a statistically significant, positive coefficient $(1.5 \%$ increase in wages per point on the reading test, and $2.4 \%$ per point on the math test). However, introducing the scores does not reduce appreciably the estimated teen-height premium. Without controlling for the test scores, the teen-height premium is estimated at $2.1 \%$ per inch in this sample. Adding the controls merely reduces the estimated teen-height premium to $1.9 \%$ per inch. A complementary approach is pursued in Appendix A where we regress the age 7 test scores on heights at different ages (see Table A1 columns 1-2). Generally, we find that each of the heights is only very weakly associated with these test scores, and we find no evidence that teen height is a systematically better predictor of these test scores. 
Comparable measures of native intelligence are not available in the NLSY. The earliest standardized measure of intellectual ability is the AFQT, an achievement test administered in 1981, when the respondents are 16 or older. We will discuss achievement tests in Section 6.

Later physical maturers might also be later cognitive or emotional maturers. If this were the case, we would expect those maturing later to, for example, get less from the same amount of schooling than their early maturing adult peers and, therefore, complete less school or do worse in the adult labor market. The notion is that at any age, being taller allows one to get more out of education. In this were the case, greater height would be beneficial at all ages and we would expect the coefficient on height at all pre-adult ages to be substantial in Table 4 . The fact that we do not see this pattern suggests that there is no advantage to earlier development per se.

Alternatively, it might be argued that puberty has a special quality among stages of development. It may be that achieving puberty enables one to start accumulating a special kind of human capital, and those who achieve puberty early (and so are taller as teens) get a head start in the accumulation process. This could be the reason for the pre-eminence of teen height among all heights in explaining adult wages. According to this hypothesis, the teen years are not special because of the environment associated with them; rather, being tall as a teen is merely a symptom of early puberty and thus the precocious achievement of a large fraction of one's ultimate height. This argument can be explored by estimating the extent to which the fraction of one's ultimate height achieved as a teen, rather than height level, matters for adult wages. Table 6 introduces the fraction of final height achieved as a teen along with teen height level. This allows us to distinguish the effect on adult wages of being fully developed as a teen from just being tall on the way to greater heights. If early puberty were the key to larger wages, then the estimated coefficient of percentage height achieved should be large.

Columns 3 and 4 of Table 6 present results from the NCDS. In these specifications we estimate of the effect on wages of teen height alone, and of the effect of teen height conditional on percentage of adult height achieved, respectively. In Column 3 we regress the log of age-33 wages on age-16 height, family background and region, and estimate a $2.4 \%$ per inch teen height premium. Column 2 adds a control for the percentage of age-33 height achieved by age 16. In these British data we find no relationship between adult wages and the fraction of adult height achieved by age-16; and adding this control leaves the estimated effect of teen height essentially unchanged. In the US data (Columns 5 and 6) we observe an identical pattern. In Column 5 we estimate a 2.2 percent teen height premium, absent a control for fraction of adult height achieved. 
As in the British data adding the control for teen development (Column 6) leaves the estimated effect of teen height level basically unchanged. Here, as in the NCDS, this percent of maturity measure does not explain the teen height wage premium.

\section{Channels}

The previous section indicates that the advantage of being a tall teen is not due to some omitted resource variable such as native intelligence, health, etc., and thus we are lead to the conclusion that being tall as an adolescent facilitates the acquisition of some form of human capital. In this section we try to get a better handle on the form of this human capital by exploring some of the channels through which teen height affects wages. Our data sets afford a rich set of alternatives to be explored. We have data on occupation choice, self-esteem measures, high school sports and clubs participation, achievement test scores, and years of completed schooling.

\section{Occupation Choice}

To investigate the correlation between teen height and occupational choice, we rank occupations according to the sample average teen height in the respondent's occupational category. We then use average occupation height as a control in our wage regression. This variable seems to play a limited role in mediating the effect of teen height (see Table 7, Columns 1-2 top and bottom panels). This means that, while tall teens earn more as adults, the premium is largely not a result of sorting across occupations. Consistent with this finding of little sorting, we find that in the US the difference between the average heights of those working in occupations with the 25th and 75th percentile of average height is only 0.48 inches (compare this with the difference between the population's 25th and 75th height percentile, which is 5 inches in the US). ${ }^{25}$

\section{Self-esteem}

Self-esteem, in light of the social-psychological theories described in the introduction, is a natural measure to consider in our search for the channels for the height premium. Our measure of self-esteem is drawn from questions asked in the 1980 wave of the NLSY, when respondents were administered the Rosenberg self-esteem scale. ${ }^{26}$

\footnotetext{
${ }^{25}$ Occupational choice appears to be similarly unimportant if we condition directly on occupation codes instead of the average height within occupation (results not shown).

${ }^{26}$ The Rosenberg Self-Esteem Scale is constructed by adding up the scores (each ranging between 1 and 4) describing the extent to which respondents agreed with 10 statements about themselves. For example, respondents were asked the extent to which they agreed with the statements "I am a person
} 
There is no self-esteem measure in the UK data. Self-esteem has a statistically significant and economically important association with wages (see Table 7, Column 3). Self-esteem, however, seems to have little to do with the teen height premium. Conditioning on self-esteem leaves the estimated teen height premium essentially unchanged. Thus, those who were tall teens do not appear to earn more because they had greater self-esteem as teens.

\section{Social Activities}

Having ruled out several possible channels through which teen height influences adult wages, we now provide evidence suggesting that participation in social activities in adolescence contributes importantly to the teen-height premium. To this end we restrict attention to the NLSY data set, which contains especially detailed information concerning participation in social activities. Those who were relatively short when young are less likely to participate in social activities that may facilitate the accumulation of productive human capital like social adaptability. We think of athletics, school clubs, and dating as examples of these types of activities. We show that participation in extracurricular activities plays a role in the teen-height premium.

Table 7, Column 4 presents estimates of the effects of height on adult wages, conditional on participation in high school social activities. Retrospective questions about participation in high school activities were asked in 1984, only to those who had finished or were expected to finish high school. Our measure of social activity is the number of non-vocational, non-academic high school clubs in which the respondent participated. ${ }^{27}$ Because height is often a criterion for participation in athletics, we separate athletics from these other high school activities. ${ }^{28}$ Last, we note that for the younger members of the sample, height in 1981 represents (at least in part) high school height. For those 19 and older in 1981, however, height in 1981 will be a noisier signal of high school height. The analysis is performed both for all white males for whom we have adequate data (Table 7, Column 4), and for those younger than 19 in 1981 alone (Table 7, Column 11).

The results for the all-age sample (Table 7, Column 4) indicate that participation

of worth" and "I have very little to be proud of." The average self-esteem score among the white male subsample is 23.93, standard deviation 2.72. We note that self-esteem was measured in 1980 , one year prior to the self-reported height measurement. Because of this time lag, our measure may be somewhat less accurate as a correlate of self-esteem in 1981.

${ }^{27}$ These clubs include youth groups, hobby clubs, student government, newspaper/yearbook, performing arts, and 'other' clubs. This list does not include, in particular, honor societies or vocational clubs. On average, the white male subsample participated in 0.69 clubs, standard deviation 1.00.

${ }^{28}$ Among the white males in our subsample, $51 \%$ participated in high school athletics. 
in social activities is associated with a statistically and economically significant wage premium. Controlling for age, height, region and family background, and other club membership, participation in high school athletics is associated with an $11.7 \%$ increase in adult wages. Participation in every additional club other than athletics is associated with a $5.1 \%$ increase in wages. When we add controls for the levels of participation in high school activities the coefficient on youth height declines by a modest $22 \%$. The estimated effect of adult height is qualitatively unchanged.

The effects of accounting for high school activities are more dramatic, however, when attention is restricted to those who were actually in high school in 1981 when their height was recorded. Table 7, Column 8 presents the basic regression for this younger group. Here we estimate that every inch of youth height is associated with a $2.6 \%$ increase in adult wages. Again the effect of adult height, while estimated at $-1.6 \%$ per inch, is statistically indistinguishable from zero. When, in Column 4 , we add controls for the levels of participation in high school activities the coefficient on youth height declines by more than $38 \%$ and is no longer statistically significant at the $10 \%$ level. Again the coefficients on participation in activities are economically meaningful and statistically significant.

We should emphasize that one must be cautious in interpreting these regressions. Participation in athletics and clubs are choice variables and we have not modelled that choice. Thus, it would be incorrect to conclude that compulsory participation in athletics and/or clubs would raise expected adult wages. Consider sports, for example. If it were success that mattered for the wage premium, requiring shorter boys to participate (and fail) in sports would have no beneficial effect. There are obviously many other plausible models consistent with our finding a relationship between teen participation in athletics and adult wages. Understanding the particular form of that relationship is important, but is beyond the scope of this paper. ${ }^{29}$

\section{Achievement Tests}

Next we ask what achievement test scores reveal about channels for the teen height premium. Controlling for achievement test scores has a considerable effect on the teen height coefficient (see Table 7, top panel Columns 5 and 12, bottom panel, Column 3) suggesting that an important channel through which teen height affects wages is captured by the achievement tests. Depending on the sample, however, the effect on

\footnotetext{
${ }^{29}$ Barron, Ewing, and Waddell (2000) analyze the link between participation in high school athletics and labor market outcomes. They find that the link can be attributed to lower cost of effort of those who participate in athletics, or to a directly productive role of athletic in training youth for the labor market.
} 
the estimated teen height premium of conditioning on achievement tests depends on whether we control for, among other things, sports and clubs participation. Table 7, Column 7 shows the estimates from the entire US sample, where we condition on all of our potential channels variables. Comparing these results with those from Table 7, Column 5, the estimated AFQT premium is $57 \%$ of what it was in the absence of conditioning on the rest of our channels measures, including sports and clubs participation. Comparing columns 4 and 7, we find that conditioning on the achievement tests, and the other channels variables reduces the coefficient on athletics to $29 \%$ of what it was unconditional of achievement tests. Comparing Columns 5 and 7 in Table 7, the degree to which conditioning on the test score explains the teen height premium is unchanged by the inclusion of controls for the other channels. In this sample, therefore, AFQT appears to be a sufficient statistic for the productive components of all of the channels measures.

Columns 8-14 of Table 7 restrict attention to the sample that was actually in high school when height was recorded in 1981. In this sample, participation in high school sports and clubs appears to have an effect on wages and the teen height premium that is independent of what is measured by AFQT. Comparing the results in Columns 12 and 14, we find that, as in the entire sample, the estimated AFQT premium is 57 percent of what it was in the absence of conditioning on sports and clubs participation. Unlike in the entire sample, however, comparing columns 11 and 14 we find that conditioning on the other channels measures reduces the coefficient on athletics symmetrically. The coefficient on athletics conditional on AFQT is 55 percent of what it is unconditional of the achievement test score.

In this younger sample, AFQT is not a sufficient statistic for the productive component of participation in sports and clubs. Comparing Columns 11 and 12 of Table 7 , the degree to which conditioning on the test score explains the teen height premium is essentially the same as that explained by conditioning on sports and clubs participation. Comparing Columns 12 and 14 in Table 7, the degree to which conditioning on the test score explains the teen height premium is here improved by the inclusion of controls for sports and clubs participation. Alone, the activities measures and test score each reduce the estimated teen height premium by 38 and 42 percent respectively. Together, along with the other channels controls, these measures reduce the estimated teen height premium by 58 percent (Table 7, Column 14).

The role played by achievement tests requires a careful interpretation. The AFQT, for example, reflects not only intellectual endowment but also education and other inputs that are the results of past experiences - in this case inputs that are correlated 
with social activities. ${ }^{30}$ The effect on the estimated teen height premium of conditioning on achievement test scores taken during or after adolescence is consistent, therefore, with a teen height premium that derives from adolescent experiences. The evidence in this paper indicates that the alternative hypothesis, that pre-adolescent intellectual endowments explain the teen height premium, is not very plausible for three reasons. First, we have seen in the NCDS that conditioning on earlier intelligence tests does not diminish the height premium, nor does teen height predict the scores of early intelligence tests (see Section 5.4). Second, since intellectual endowment is partly heritable, the argument developed in Section 5.2 casts doubt on the importance of that endowment as an explanation for the teen height premium. Third, we find no evidence that the teen height premium might reflect an early development premium (see Section 5.4). Overall, the evidence suggests that to the extent that achievement test scores help explain the teen height premium, this is not because they partly reflect pre-adolescent intellectual endowment, but rather because they also reflect schooling and other adolescent experiences. ${ }^{31}$

\section{Not Statistical Discrimination}

We argue that, if short adolescents participate less in social or AFQT-enhancing activities, it is not because they anticipate a lower return to these factors when adult. Again restricting attention to the NLSY data, and those who were 19 or younger in 1981, we estimate the return to participation in social activities and to AFQT, depending on height. In two separate regressions, we investigate whether the estimated

\footnotetext{
${ }^{30}$ While it is plausible that achievement test scores reflect some component of intellectual endowments (these could be intelligence, persistence, social adaptability, etc.) the notion that achievement tests like the AFQT measure only pre-adolescent endowments has been discredited. It is known, for example, that the AFQT score increases with age and education. Hansen, Heckman and Mullen (2003), for example, find an important effect of education on AFQT scores (see also Neal and Johnson 1996). Our analysis has added to this evidence; as discussed before, while for individuals in the NLSY who take the AFQT later in life that score is a sufficient statistic (with respect to wages) for participation in high school sport and clubs, the same is not true when the AFQT is measured at adolescence (see below).

${ }^{31}$ To the extent that years of schooling explain the teen height premium, that effect is mediated by differences in achievement tests scores. Without controlling for achievement test scores, the estimated teen height premium decreases modestly when we control for schooling (see Table 7, top panel, Columns 6 and 13, and bottom panel Column 4). When we control for achievement tests, however, the teen height premium is unaffected by the inclusion of years of completed schooling (results not shown). This means that the ability of years of schooling to explain the teen height premium is mediated by the achievement tests scores. We view this finding as further evidence that, with regard to the teen height premium, achievement test scores should be interepreted as an outcome of individual choice rather than an external resource.
} 
returns to participation in social activities and AFQT are significantly different for those white male workers who were less than median height as adults that for those who were at least median height as adults. Conditioning only on age, family background and region, we find that the coefficients on social activities and AFQT do not differ significantly, or systematically between the two regressions. Among those who grew to less than median adult height the estimated coefficient on participation in athletics is 0.092, while for those who grew to at least median adult height the estimated coefficient is larger (0.145), though we can not reject the null hypothesis that the two coefficients are the same. The estimated coefficient on participation in clubs among the shorter adult group is actually larger (0.063) than that for the taller group (0.037), though again we cannot reject the null hypothesis that the coefficients are the same. ${ }^{32}$ For the AFQT, the estimated coefficient is also larger for the shorter group (0.007) than for the taller group (0.005). Thus we find little evidence that the returns to investing in social or AFQT-enhancing activities when young are significantly or systematically different depending on whether one forecasts becoming a tall or short adult. ${ }^{33}$

\section{Discussion}

\section{Parents-Children Correlation in Height}

If the correlation between parents' teen or adult height and the child's teen height is substantial, then the children of tall parents are advantaged in expectation on the labor market. This advantage could be magnified if parents are found to match assortatively by height (i.e., taller men tend to have children with taller women). While the NLSY does not report the subject's parent's height, the NCDS allows us to explore these issues. Unfortunately we do not have a measure of the NCDS parents' teen height, but we have a (self-reported) measure of the parents' adult height. We first compute the correlation coefficient between the parents' adult height and the child's teen height. The coefficient is 0.35 for fathers and 0.40 for mothers. Thus, a son of a tall couple enjoys a relatively large advantage, in expectation, due to his superior expected teen height.

Because the correlation between parents' and children's teen height is high, we might worry that the child's teen height proxies for the parents' height, and thus the estimated coefficient on the child's teen height may reflect some parental endowment

\footnotetext{
${ }^{32}$ Similar results hold when we analyze the entire sample of white male workers rather than only this younger subsample.

${ }^{33}$ This evidence, however, must be interpreted cautiously. See Moro and Norman (2003).
} 
that is not completely captured by our measures of resources. The results in Table 4 indicate, however, that the estimate of the teen height coefficient is unaffected by the inclusion of his father's height (the same is true for mother's height, results omitted). This result suggests that the beneficial effects of teen height do not perpetuate across generations except through height itself.

\section{Human Growth Hormone Replacement Therapy}

Since 1985, pathologies resulting in short stature have been treated with injections of synthetic human growth hormone $(\mathrm{HGH})$ replacement in the form of somatropin, the drug's generic name. In July 2003, Humatrope (the name brand of somatropin from Eli Lilly) was approved by the FDA for use by patients of short stature who display normal levels of HGH. The total sales of the five brands currently on the market reached $\$ 1.5$ billion in 2001. It is likely that FDA approval will mean an even larger use of somatropin.

From our viewpoint, somatropin provides a previously unavailable means of control over a variable, teen height, that in our data sets is not under the control of individuals. As such, our data allow us to estimate the monetary returns from the previously unavailable medical option and compare these returns to the monetary cost of treatment.

Treatment with HGH varies depending on the weight of the patient. For a child who weighs 30 kilograms, the annual treatment would cost approximately $\$ 25,000$ in 2003. The average length of treatment is 6.5 years. ${ }^{34}$ Using an annual discount factor of 0.97, the discounted monetary cost at age 10 of starting a 6-year somatropin treatment course equals $\$ 135,000$. This figure must be compared with the discounted additional earnings from the expected increase in teen height. In the more relevant FDA cited study, the mean final height exceeded mean height predicted at enrollment in the study by nearly three inches. If we take our lowest estimate of the teen height premium of 1.9 percent per year, and assume a 30-year working career at a constant yearly wage, the minimum wage that would justify investing in the somatropin treatment at age 10 is $\$ 149,910$. If we take our highest estimate of the teen height premium of 2.7 percent, investment is justified by those earning $\$ 105,500$.This back-of-the-envelope calculation suggests that the monetary benefits of somatropin treatment are not incommensurate with the cost, and that a sizable fraction of the population might be willing to consider treatment purely on an economic basis. Of course, one can reasonably suppose that there are other benefits associated with greater height that are not pecuniary.

\footnotetext{
${ }^{34}$ See Mele (2003). In addition, there are non-trivial non-monetary costs to be factored in, as the treatment is administered daily by injection.
} 


\section{Conclusions}

Labor market outcomes differ depending on a person's physical characteristics, and the resulting disparities have motivated a large body of research focussed on identifying the channels through which these disparities develop. In this paper we took up this agenda with respect to height. First, we found that the magnitude of wage differences associated with height is similar to that associated with racial differences; without correcting for education or occupation choice, we estimate the black-white wage gap to be approximately $15 \%$ among males in the NLSY. Depending on our specification, this estimated gap is approximated by the difference in wages for two men whose heights differ by six to eight inches. We then took advantage of a special feature of height relative to other bases of wage disparity, such as race and gender: height changes over time, so that a relatively tall 16-year old may turn out to be a relatively short adult, and vice versa. This time-variation allowed us to investigate the stage of development at which having the characteristic (in our case, being short) most strongly determines the wage disparity. We found that being relatively short through the teen years, as opposed to adulthood or early childhood, essentially determines the returns to height. We documented that the beneficial effects of teen height are not complementary with any particular vocation path; instead, they manifest themselves in a higher level of achievement in all vocation categories, broadly defined. We suggested that social effects might be an important channel for the emergence of the height premium. We found that teen height is predictably greater for sons of tall parents. This suggests that, similar to race-based disparities (but unlike gender-based disparities), there is an expected wage penalty incurred by the as-yet-unborn children of short parents. Finally, we used our estimates of the return to teen height to evaluate the monetary incentive to undertake a relatively new treatment that boosts teen height, human growth hormone therapy.

Our analysis can be extended both to blacks and to women. With respect to blacks, sample sizes are smaller for this group, and nearly non-existent in the UK data we use; the estimates in the US are, however, quite similar to those for white men. The findings for white women are different. While we find an economically substantial, and sometimes statistically significant, adult height premium for white women in both the UK and the US, the height premium is not attributable to teen height. This finding must be qualified by the recognition that proper estimates of the wage offer functions for women should take account of the important labor market participation decision, and the results described here ignore the selection issue. While far from conclusive, we 
view these results for females as suggesting that the relationship between productive endowments and the timing of physical development is different for males and females. Or, as plausible, in our view, the social-psychological returns to earlier development are different for males and females; research in psychology indicates that earlier physical development is a hindrance for girls (see, e.g., Brooks-Gunn, et al., 1985, Ge, et al., 1996, and Graber, 1997). When considered in light of our results for males, the absence of a teen height premium for females reinforces the notion that the estimated teen height premium for males is not merely the result of a correlation between earlier physical development and omitted productive endowments. If the male teen height premium were simply a premium for resources associated with earlier development then we might expect to observe similar benefits to females who developed earlier.

A number of questions pertaining to the height premium are left open by our analysis. Assuming there are valuable skills that are acquired through participation in clubs and athletics, what precisely is acquired? Likely candidates are the interpersonal skills acquired through social interactions, social adaptability from working in groups, and discipline and motivation that result from participation. We also do not know that it is discrimination within athletics and other extracurricular activities that accounts for shorter teens' lower participation. It may be, for example, that earlier treatment has made these youths more sensitive to slights, and that as a result they withdraw from such interactions. More detailed data on the activities that youths engage in, and the job market consequences would permit a better understanding of the production process of social skills. 


\section{A Teen Height not a Superior Correlate of Endow- ments Relative to Other Heights}

[Insert table A1] 


\section{References}

[1] Averett, Susan, and Sanders Korenman (1996). "The Economic Reality of The Beauty Myth." Journal of Human Resources 31(2):304-330.

[2] Behrman, Jere, and Mark Rosenzweig (2001). "The Returns to Increasing Body Weight." Working Paper. University of Pennsylvania.

[3] Barron, John M., Bradley T. Ewing, and Glen R. Waddell "The Effects of High School Athletic Participation on Education and Labor Market Outcomes." The Review of Economics and Statistics, August 2000, 82(3), pp. 409-21.

[4] Blau, Francine and Lawrence Kahn. "Swimming Upstream: Trends in the Gender Wage Differential in the 1980s." Journal of Labor Economics 15(1, Part 1) 1997: $1-42$.

[5] Cain, Glen (1986). "The Economic Analysis of Labor Market Discrimination: A Survey." In Handbook of Labor Economics, vol. 1, Eds. Orley Ashenfelter and Richard Layard. Amsterdam: North-Holland.

[6] Case, Ann, Angela Fertig and Christina Paxson (2003). "From Cradle to Grave? The Lasting Impact of Childhood Health and Circumstance." Princeton University Center for Health and Wellbeing. Working Paper.

[7] Damon, Albert, Howard Stoudt, and Ross McFarland The Human Body in Equipment Design, Harvard University Press, Cambridge MA 1966.

[8] Cawley, John, Karen Conneely, James Heckman, Edward Vytlacil "Cognitive Ability, Wages, and Meritocracy." In Devlin, Bernie, Stephen Fienberg, Daniel Resnick, Kathryn Roeder, eds. Intelligence, Genes, and Success: Scientists Respond to the Bell Curve Springer Verlag, New York, 1997.

[9] Elias, P., and David Blanchflower (1988). "The Occupations , Earnings and Work Histories of Young Adults - Who Gets the Good Jobs?" London England, Department of Employment.

[10] Frieze, Irene H., Olson, Josephine E., and Deborah C. Good (1990). "Perceived and Actual Discrimination in the Salaries of Male and Female Managers. Journal of Applied Social Psychology 20(1):46-67. 
[11] Hamermesh, Daniel S., and Jeffrey E. Biddle (1994). "Beauty and the Labor Market." American Economic Review 84(5):1174-1194.

[12] Hansen, Karsten, James Heckman and Kathleen Mullen (2003). "The Effect of Schooling and Ability on Achievement Test Scores." Forthcoming, Journal of Econometrics.

[13] Heckman, James J. (2000) "Policies to Foster Human Capital." Research in Economics 54(1):3-56.

[14] _____ (1998). "Detecting Discrimination." Journal of Economic Perspectives 12(2):101-116.

[15] Loh, Eng Seng (1993). "The Economic Effects of Physical Appearance." Social Science Quarterly. 74 (2):420-38.

[16] Martel, Leslie F. and Henry B. Biller (1987). Stature and Stigma: The Biopsychosocial Development of Short Males. Lexington Books. Lexington, Mass.

[17] Mele, Joy (2003). "Statistical Review and Evaluation: Clinical Studies" NDA \#19-640/SE1-033. Food and Drug Administration Center for Drug Evaluation and Research Report (on file with the authors).

[18] Moro, Andrea and Peter Norman (2003). "Empirical Implications of Statistical Discrimination on the Returns to Measures of Skill "Empirical Implications of Statistical Discrimination on the Returns to Measures of Skill." Annales d'Économie et de Statistique.

[19] National Center for Health Statistics, US. Department of Health and Human Services (1987). "Anthropometric Reference Data and Prevalence of Overweight: United States, 1976-80." DHHS Publication No., (PHS) 87-1688.

[20] Neal, Derek, and William Johnson (1996). "The Role of Premarket Factors in Black-White Wage Differences." Journal of Political Economy. 104 (5):869-95.

[21] Persico, Nicola, Andrew Postlewaite and Dan Silverman (2003). "The Effect of Adolescent Experience on Labor Market Outcomes: The Case of Height." PIER Working Paper 03-036.

[22] Roche, Alex F. Growth, Maturation, and Body Composition: the Fels Longitudinal Study 1929-1991. Cambridge University Press, Cambridge UK 1992. 
[23] Sargent, James D., and David G. Blanchflower (1994). "Obesity and Stature in Adolescence and Earnings in Young Adulthood: Analysis of a British Birth Cohort." Archives of Pediatric and Adolescent Medicine 148:681-687.

[24] Steckel, Richard H. "Stature and the Standard of Living," Journal of Economic Literature, 33(4), Dec. 1995, pp. 1903-40. 


\begin{tabular}{|c|c|c|c|c|c|}
\hline Britain -- NCDS $^{1}$ & Height age 16 & Height age 33 & $\Delta$ age $16-33$ & Height age 11 & Height age 7 \\
\hline Mean & 67.28 & 69.81 & 2.54 & 56.94 & 48.50 \\
\hline Median & 67.32 & 69.69 & 1.97 & 57.01 & 49.02 \\
\hline Standard deviation & 3.01 & 2.62 & 1.99 & 2.63 & 2.16 \\
\hline $25^{\text {th }}$ percentile & 65.35 & 68.11 & 1.18 & 55.00 & 47.01 \\
\hline $75^{\text {th }}$ percentile & 69.29 & 71.65 & 3.54 & 58.74 & 50.00 \\
\hline $\mathrm{N}$ & 1772 & 1772 & 1772 & 1684 & 1702 \\
\hline US -- NLSY ${ }^{2}$ & Height 1981 & Height 1985 & $\Delta 1981-85$ & & \\
\hline \multicolumn{6}{|l|}{ Entire subsample } \\
\hline Mean & 70.41 & 70.69 & 0.28 & & \\
\hline Median & 70 & 70 & 0 & & \\
\hline Standard deviation & 2.85 & 2.77 & 1.44 & & \\
\hline $25^{\text {th }}$ percentile & 68 & 68 & 0 & & \\
\hline $75^{\text {th }}$ percentile & 73 & 73 & 1 & & \\
\hline $\mathrm{N}$ & 2603 & 2603 & 2603 & & \\
\hline \multicolumn{6}{|l|}{$\begin{array}{l}\text { Those with } \\
\Delta \text { height }>0\end{array}$} \\
\hline Mean & 69.54 & 71.22 & 1.68 & & \\
\hline Median & 69 & 70 & 1 & & \\
\hline Standard deviation & 3.09 & 2.73 & 1.51 & & \\
\hline $25^{\text {th }}$ percentile & 68 & 69 & 1 & & \\
\hline $75^{\text {th }}$ percentile & 72 & 74 & 3 & & \\
\hline $\mathrm{N}$ & 618 & 618 & 618 & & \\
\hline \multicolumn{6}{|c|}{$\begin{array}{l}\text { US Measured heights for white males, ages } 18-24 \text {, from the National Health and Nutrition } \\
\text { Examination Survey } 1976-1980^{3}\end{array}$} \\
\hline Mean & 69.8 & & & & \\
\hline Median & 69.7 & & & & \\
\hline Standard deviation & 2.8 & & & & \\
\hline $25^{\text {th }}$ percentile & 67.9 & & & & \\
\hline $75^{\text {th }}$ percentile & 71.6 & & & & \\
\hline $\mathrm{N}$ & 846 & & & & \\
\hline
\end{tabular}

${ }^{1}$ The subsample consists only of the full-time, white male workers in the NCDS for whom there is a measure of height at age 33 and 16, and information on wages and family background. The sample is further restricted when we consider those with data on age-11 and age-7 height.

${ }^{2}$ The subsample consists only of the white male respondents to the NLSY for whom there is a measure of height at in 1985 and 1981, and information on family background. The NLSY's oversample of poor whites is excluded.

${ }^{3}$ Source: National Center for Health Statistics (1987), Table 13. 


\begin{tabular}{|c|c|c|c|c|}
\hline & \multicolumn{2}{|c|}{ Britain -- NCDS } & \multicolumn{2}{|c|}{ US -- NLSY } \\
\hline & $\begin{array}{c}\text { Adult Height } \\
\text { Median or Below }\end{array}$ & $\begin{array}{l}\text { Adult Height } \\
\text { Above Median }\end{array}$ & $\begin{array}{c}\text { Adult Height } \\
\text { Median or Below }\end{array}$ & $\begin{array}{l}\text { Adult Height } \\
\text { Above Median }\end{array}$ \\
\hline Adult Characteristics: & $\begin{array}{l}\text { Mean } \\
(\mathrm{SE})\end{array}$ & $\begin{array}{l}\text { Mean } \\
(\mathrm{SE})\end{array}$ & $\begin{array}{l}\text { Mean } \\
\text { (SE) }\end{array}$ & $\begin{array}{l}\text { Mean } \\
(\mathrm{SE})\end{array}$ \\
\hline $\begin{array}{l}\text { Teen height } \\
\text { (inches) }\end{array}$ & $\begin{array}{l}65.55^{*} \\
(0.08)\end{array}$ & $\begin{array}{l}69.12 \\
(0.08)\end{array}$ & $\begin{array}{c}68.19 * \\
(0.07)\end{array}$ & $\begin{array}{l}72.23 \\
(0.06)\end{array}$ \\
\hline $\begin{array}{l}\text { Adult height } \\
\text { (inches) }\end{array}$ & $\begin{array}{l}67.80^{*} \\
(0.05)\end{array}$ & $\begin{array}{l}71.96 \\
(0.06)\end{array}$ & $\begin{array}{c}68.25^{*} \\
(0.06)\end{array}$ & $\begin{array}{l}72.70 \\
(0.05)\end{array}$ \\
\hline Age & $\begin{array}{l}33.0 \\
(\ldots)\end{array}$ & $\begin{array}{l}33.0 \\
(\ldots)\end{array}$ & $\begin{array}{l}35.34 \\
(0.07)\end{array}$ & $\begin{array}{l}35.31 \\
(0.07)\end{array}$ \\
\hline Ln(wage per hour) & $\begin{array}{l}1.99 * \\
(0.02)\end{array}$ & $\begin{array}{l}2.10 \\
(0.02)\end{array}$ & $\begin{array}{l}2.58^{*} \\
(0.03)\end{array}$ & $\begin{array}{c}2.68 \\
(0.02)\end{array}$ \\
\hline $\begin{array}{l}\text { Years of completed } \\
\text { schooling }\end{array}$ & $\begin{array}{l}11.04^{*} \\
(0.03)\end{array}$ & $\begin{array}{l}11.19 \\
(0.03)\end{array}$ & $\begin{array}{l}13.38^{*} \\
(0.09)\end{array}$ & $\begin{array}{l}13.79 \\
(0.08)\end{array}$ \\
\hline $\begin{array}{l}\text { Ever } \\
\text { married (\%) }\end{array}$ & $\begin{array}{l}79.89 \\
(1.34)\end{array}$ & $\begin{array}{l}80.09 \\
(1.38)\end{array}$ & $\begin{array}{l}78.84 * \\
(1.42)\end{array}$ & $\begin{array}{l}83.15 \\
(1.17)\end{array}$ \\
\hline $\begin{array}{l}\text { Divorced or } \\
\text { separated }(\%)^{1}\end{array}$ & $\begin{array}{l}16.74 \\
(1.40)\end{array}$ & $\begin{array}{l}14.97 \\
(1.38)\end{array}$ & $\begin{array}{c}20.71^{*} \\
(1.59)\end{array}$ & $\begin{array}{l}15.90 \\
(1.26)\end{array}$ \\
\hline \multicolumn{5}{|l|}{ Family Background: } \\
\hline $\begin{array}{l}\text { Mother's years of } \\
\text { schooling }\end{array}$ & $\begin{array}{l}10.43^{*} \\
(0.05)\end{array}$ & $\begin{array}{l}10.57 \\
(0.06)\end{array}$ & $\begin{array}{l}11.83 * \\
(0.08)\end{array}$ & $\begin{array}{l}12.29 \\
(0.07)\end{array}$ \\
\hline $\begin{array}{l}\text { Mother skilled/ } \\
\text { professional (\%) }\end{array}$ & $\begin{array}{l}56.67 \\
(1.64) \\
\end{array}$ & $\begin{array}{l}54.66 \\
(1.70) \\
\end{array}$ & $\begin{array}{l}7.20^{*} \\
(0.85)\end{array}$ & $\begin{array}{l}9.98 \\
(0.89)\end{array}$ \\
\hline $\begin{array}{l}\text { Father's years of } \\
\text { schooling }\end{array}$ & $\begin{array}{l}11.29^{*} \\
(0.04)\end{array}$ & $\begin{array}{l}11.50 \\
(0.06)\end{array}$ & $\begin{array}{l}12.14^{*} \\
(0.10)\end{array}$ & $\begin{array}{l}12.66 \\
(0.10)\end{array}$ \\
\hline $\begin{array}{l}\text { Father skilled/ } \\
\text { professional (\%) }\end{array}$ & $\begin{array}{l}79.87 \\
(1.32)\end{array}$ & $\begin{array}{l}82.87 \\
(1.29)\end{array}$ & $\begin{array}{l}12.78 \\
(1.09)\end{array}$ & $\begin{array}{l}14.92 \\
(1.06)\end{array}$ \\
\hline $\begin{array}{l}\text { Number of } \\
\text { siblings }\end{array}$ & $\begin{array}{l}3.14^{*} \\
(0.05)\end{array}$ & $\begin{array}{l}2.89 \\
(0.05)\end{array}$ & $\begin{array}{l}2.99 \\
(0.06) \\
\end{array}$ & $\begin{array}{c}2.91 \\
(0.06) \\
\end{array}$ \\
\hline $\mathrm{N}$ & 914 & 858 & 931 & 1132 \\
\hline
\end{tabular}

* Indicates means are statistically different at the $5 \%$ confidence level.

${ }^{1}$ Conditional on having been married.

Notes: Teen height is height recorded at age 16 (NCDS), or in 1981 (NLSY), adult height is height recorded at age 33 (NCDS), or 1985 (NLSY). Log wages are in measured in 1991 pounds (NCDS) and 1996 dollars (NLSY), and are for full-time workers only. For the NCDS, years of schooling equal the age at which the respondent (or parent) left school minus five. Parents are identified as skilled (professional) if they work in a professional and or skilled, non-manual (NCDS) or professional/managerial (NLSY) occupation. 


\begin{tabular}{|c|c|c|c|c|c|c|c|c|}
\hline & \multicolumn{4}{|c|}{ Britain -- NCDS } & \multicolumn{4}{|c|}{ US -- NLSY } \\
\hline & (1) & (2) & (3) & (4) & (5) & (6) & (7) & $(8)$ \\
\hline \multicolumn{9}{|l|}{ Covariates } \\
\hline $\begin{array}{l}\text { Adult height } \\
\text { (inches) }\end{array}$ & $\begin{array}{c}0.027 \\
(0.0053)\end{array}$ & $\begin{array}{c}0.022 \\
(0.0052)\end{array}$ & $\begin{array}{c}0.004 \\
(0.0074)\end{array}$ & $\begin{array}{c}0.005 \\
(0.0073)\end{array}$ & $\begin{array}{c}0.025 \\
(0.0062)\end{array}$ & $\begin{array}{c}0.018 \\
(0.0060)\end{array}$ & $\begin{array}{c}0.002 \\
(0.0096)\end{array}$ & $\begin{array}{l}-0.004 \\
(0.0091)\end{array}$ \\
\hline $\begin{array}{l}\text { Youth height } \\
\text { (inches) }\end{array}$ & & & $\begin{array}{c}0.026 \\
(0.0066)\end{array}$ & $\begin{array}{c}0.021 \\
(0.0066)\end{array}$ & & & $\begin{array}{c}0.027 \\
(0.0095)\end{array}$ & $\begin{array}{c}0.026 \\
(0.0090)\end{array}$ \\
\hline Age & $\ldots$ & $\ldots$ & 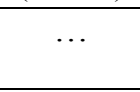 & $\ldots$ & $\begin{array}{c}0.028 \\
(0.0066) \\
\end{array}$ & $\begin{array}{c}0.027 \\
(0.0065) \\
\end{array}$ & $\begin{array}{c}0.024 \\
(0.0067) \\
\end{array}$ & $\begin{array}{c}0.023 \\
(0.0065) \\
\end{array}$ \\
\hline $\begin{array}{l}\text { Mother's years of } \\
\text { schooling }\end{array}$ & & $\begin{array}{c}0.016 \\
(0.0104)\end{array}$ & & $\begin{array}{c}0.016 \\
(0.0104)\end{array}$ & & $\begin{array}{c}0.025 \\
(0.0092)\end{array}$ & & $\begin{array}{c}0.023 \\
(0.0092)\end{array}$ \\
\hline $\begin{array}{l}\text { Mother skilled/ } \\
\text { professional }\end{array}$ & & $\begin{array}{l}-0.080 \\
(0.0357)\end{array}$ & & $\begin{array}{l}-0.074 \\
(0.0356)\end{array}$ & & $\begin{array}{c}0.019 \\
(0.0608)\end{array}$ & & $\begin{array}{c}0.024 \\
(0.0606)\end{array}$ \\
\hline $\begin{array}{l}\text { Father's years of } \\
\text { schooling }\end{array}$ & & $\begin{array}{c}0.008 \\
(0.0086)\end{array}$ & & $\begin{array}{c}0.007 \\
(0.0087)\end{array}$ & & $\begin{array}{c}0.030 \\
(0.0065)\end{array}$ & & $\begin{array}{c}0.030 \\
(0.0065)\end{array}$ \\
\hline $\begin{array}{l}\text { Father skilled/ } \\
\text { professional }\end{array}$ & & $\begin{array}{c}0.135 \\
(0.0467)\end{array}$ & & $\begin{array}{c}0.130 \\
(0.0465)\end{array}$ & & $\begin{array}{c}0.050 \\
(0.0459)\end{array}$ & & $\begin{array}{c}0.052 \\
(0.0458)\end{array}$ \\
\hline $\begin{array}{l}\text { Number of } \\
\text { siblings }\end{array}$ & & $\begin{array}{l}-0.033 \\
(0.0084)\end{array}$ & & $\begin{array}{l}-0.029 \\
(0.0084) \\
\end{array}$ & & $\begin{array}{l}-0.023 \\
(0.0077) \\
\end{array}$ & & $\begin{array}{l}-0.023 \\
(0.0077) \\
\end{array}$ \\
\hline $\mathrm{N}$ & 1772 & 1772 & 1772 & 1772 & 1577 & 1577 & 1577 & 1577 \\
\hline Adjusted $\mathrm{R}^{2}$ & 0.032 & 0.047 & 0.037 & 0.049 & 0.031 & 0.092 & 0.034 & 0.094 \\
\hline F-Statistic (K,N-K-1) & 9.99 & 10.25 & 11.47 & 10.97 & 9.86 & 15.52 & 8.82 & 14.31 \\
\hline
\end{tabular}

Standard errors robust to heteroskedasticity are in parentheses.

Notes: See notes for Table 2. Sample consists only of white male, full-time workers. Each specification includes controls for region and a constant term, results omitted. 


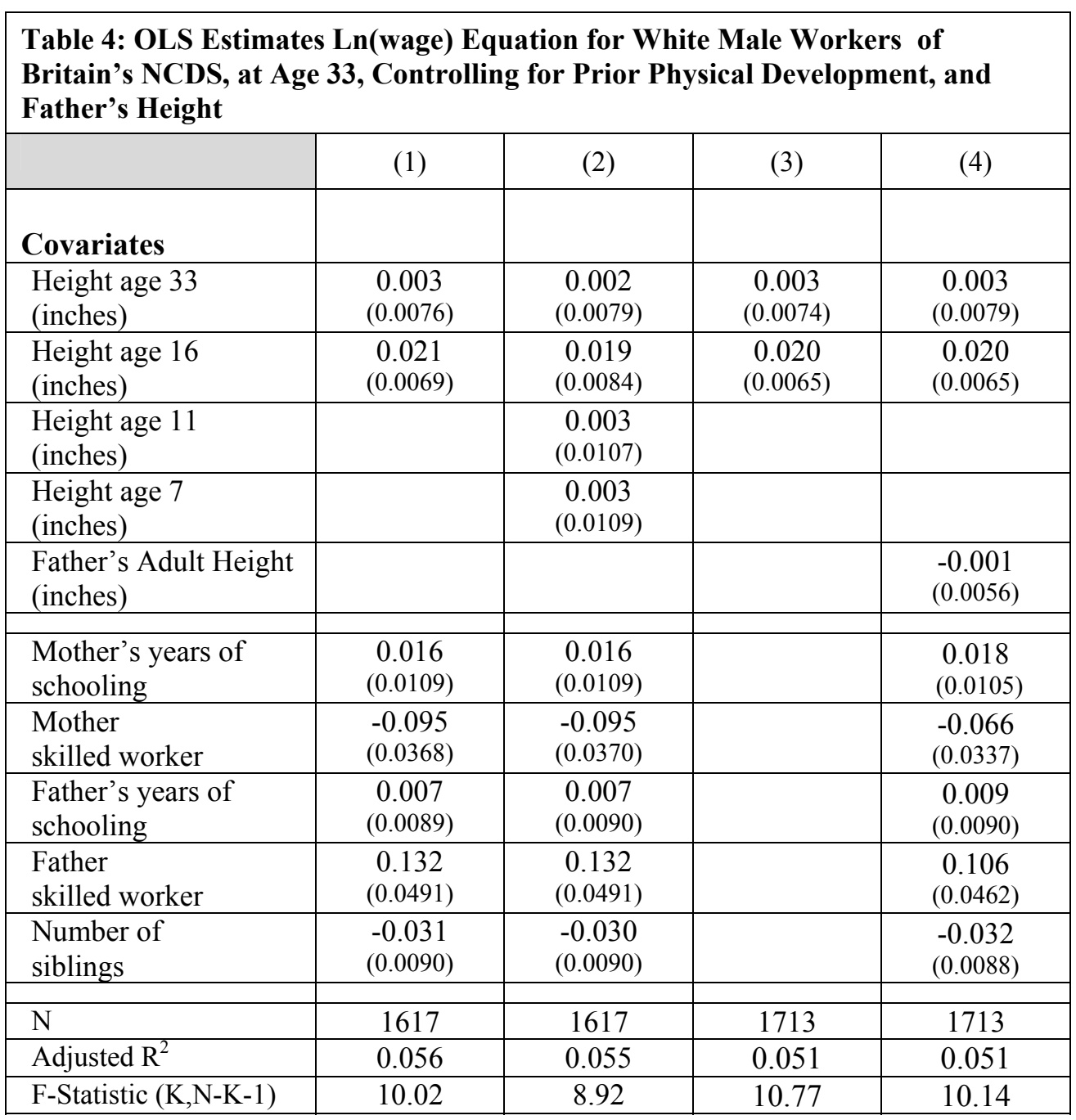

Standard errors robust to heteroskedasticity are in parentheses.

Sample consists only of full time workers. Equations include controls for region and a constant term, results omitted

Notes: See notes for Tables 2 and 3. 


\begin{tabular}{|c|c|c|c|c|c|c|c|c|c|c|c|c|c|}
\hline & \multicolumn{6}{|c|}{ Britain -- NCDS } & & \multicolumn{6}{|c|}{ US -- NLSY } \\
\hline & (1) & (2) & (3) & (4) & (5) & (6) & & (5) & (6) & (7) & (8) & (9) & (10) \\
\hline Covariates & & & & & & & Covariates & & & & & & \\
\hline $\begin{array}{l}\text { Height age } 33 \\
\text { (inches) }\end{array}$ & $\begin{array}{c}0.007 \\
(0.0079)\end{array}$ & $\begin{array}{c}0.006 \\
(0.078)\end{array}$ & $\begin{array}{c}0.007 \\
(0.0079)\end{array}$ & $\begin{array}{c}0.006 \\
(0.0078)\end{array}$ & $\begin{array}{c}0.006 \\
(0.0074)\end{array}$ & $\begin{array}{c}0.006 \\
(0.0077)\end{array}$ & $\begin{array}{l}\text { Height in } 1985 \\
\text { (inches) }\end{array}$ & $\begin{array}{l}-0.006 \\
(0.0092)\end{array}$ & $\begin{array}{l}-0.006 \\
(0.0092)\end{array}$ & $\begin{array}{l}-0.006 \\
(0.0092)\end{array}$ & $\begin{array}{l}-0.006 \\
(0.0092)\end{array}$ & $\begin{array}{c}-0.004 \\
(0.0090)\end{array}$ & $\begin{array}{l}-0.006 \\
(0.0091)\end{array}$ \\
\hline $\begin{array}{l}\text { Height age } 16 \\
\text { (inches) }\end{array}$ & $\begin{array}{c}0.020 \\
(0.0073)\end{array}$ & $\begin{array}{l}0.020 \\
(0.0073)\end{array}$ & $\begin{array}{c}0.020 \\
(0.0073)\end{array}$ & $\begin{array}{l}0.020 \\
(0.0073)\end{array}$ & $\begin{array}{c}0.020 \\
(0.0066)\end{array}$ & $\begin{array}{c}0.021 \\
(0.0089)\end{array}$ & $\begin{array}{l}\text { Height in } 1981 \\
\text { (inches) }\end{array}$ & $\begin{array}{c}0.028 \\
(0.0092)\end{array}$ & $\begin{array}{c}0.027 \\
(0.0093)\end{array}$ & $\begin{array}{c}0.028 \\
(0.0092)\end{array}$ & $\begin{array}{c}0.027 \\
(0.0092)\end{array}$ & $\begin{array}{c}0.026 \\
(0.0090)\end{array}$ & $\begin{array}{c}0.028 \\
(0.0096)\end{array}$ \\
\hline Age & $* *$ & $* *$ & $* *$ & $* *$ & $* *$ & $* *$ & Age & $\begin{array}{c}0.023 \\
(0.0066) \\
\end{array}$ & $\begin{array}{c}0.023 \\
(0.0066) \\
\end{array}$ & $\begin{array}{c}0.023 \\
(0.0066) \\
\end{array}$ & $\begin{array}{c}0.024 \\
(0.0066) \\
\end{array}$ & $\begin{array}{c}0.023 \\
(0.0065) \\
\end{array}$ & $\begin{array}{c}0.026 \\
(0.0069) \\
\end{array}$ \\
\hline $\begin{array}{l}\# \text { health conditions } \\
\text { age } 16\end{array}$ & & $\begin{array}{c}-0.052 \\
(0.0262)\end{array}$ & & $\begin{array}{l}-0.049 \\
(0.0276)\end{array}$ & & & $\begin{array}{l}\text { Health limits kind of } \\
\text { work } 79\end{array}$ & & $\begin{array}{l}-0.156 \\
(0.0788)\end{array}$ & & $\begin{array}{l}-0.216 \\
(0.100)\end{array}$ & & \\
\hline $\begin{array}{l}\# \text { health conditions } \\
\text { age } 7\end{array}$ & & & $\begin{array}{l}-0.046 \\
(0.0406)\end{array}$ & $\begin{array}{l}-0.029 \\
(0.0434)\end{array}$ & & & $\begin{array}{l}\text { Health limits } \\
\text { amount of work } 79\end{array}$ & & & $\begin{array}{l}0.026 \\
(0.086)\end{array}$ & $\begin{array}{c}0.158 \\
(0.120)\end{array}$ & & \\
\hline $\begin{array}{l}\text { Weight age } 33 \\
(\mathrm{~kg})\end{array}$ & & & & & & $\begin{array}{c}-0.0008 \\
(0.001)\end{array}$ & $\begin{array}{l}\text { Weight in } 1985 \\
\text { (kg) }\end{array}$ & & & & & & $\begin{array}{c}0.004 \\
(0.0023)\end{array}$ \\
\hline $\begin{array}{l}\text { Weight age } 16 \\
(\mathrm{~kg})\end{array}$ & & & & & & $\begin{array}{l}-0.0001 \\
(0.0021) \\
\end{array}$ & $\begin{array}{l}\text { Weight in } 1981 \\
(\mathrm{~kg})\end{array}$ & & & & & & $\begin{array}{c}-0.004 \\
(0.0025)\end{array}$ \\
\hline $\mathrm{N}$ & 1546 & 1546 & 1546 & 1546 & 1752 & 1752 & $\mathrm{~N}$ & 1558 & 1558 & 1558 & 1558 & 1577 & 1577 \\
\hline Adjusted $\mathrm{R}^{2}$ & 0.049 & 0.049 & 0.093 & 0.049 & 0.051 & 0.050 & Adjusted $\mathrm{R}^{2}$ & 0.094 & 0.095 & 0.093 & 0.096 & 0.094 & 0.095 \\
\hline F-Stat. (K,N-K-1) & 10.26 & 9.79 & 9.66 & 9.26 & 10.74 & 9.56 & F-Stat. (K,N-K-1) & 15.68 & 13.39 & 12.86 & 12.50 & 14.31 & 12.56 \\
\hline
\end{tabular}

Standard errors robust to heteroskedasticity are in parentheses.

Notes: See notes for Tables 2 and 3. In the NCDS, at age 7 the possible health conditions include slight, moderate, or severe: general motor handicap, disfiguring condition, mental retardation, emotional maladjustment, head or neck abnormality, upper limb abnormality, lower limb abnormality, spine abnormality, respiratory system problem, alimentary system problem, urogenital system problem, heart condition, blood abnormality, skin condition, epilepsy, other central nervous system condition, diabetes, and any other condition. The possible conditions at age 16 are the same except: disfiguring condition is replaced by general physical abnormality, emotional maladjustment is replaced by emotional/behavioral problem, and eye, hearing and speech defects are also included. In the NLSY, respondents were asked in 1979 a) whether their health limited the kind of work they could do and b) whether their health limited the amount of work they could do. In the UK data, two extreme values of the weight distribution -- a respondent reporting a weight of $252 \mathrm{lbs}$ at age 16 and a respondent with a recorded weight of $1741 \mathrm{lbs}$ at age 33 -- were omitted from the sample. Specifications include controls for family background, region, and a constant term results not presented 


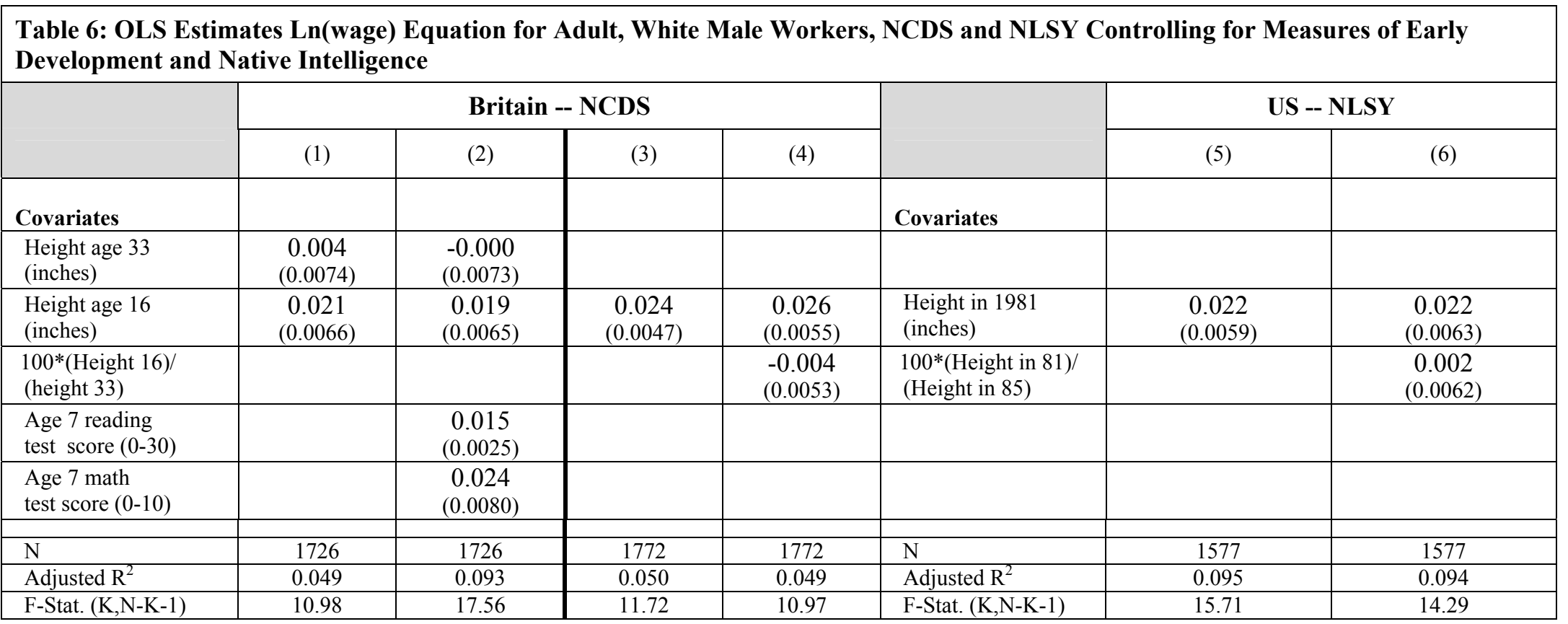

Standard errors robust to heteroskedasticity are in parentheses.

Sample consists only of full time workers. Equations include controls for family background, region, a constant term, and age in the US data, results omitted

Notes: See notes for Tables 2 and 3. 


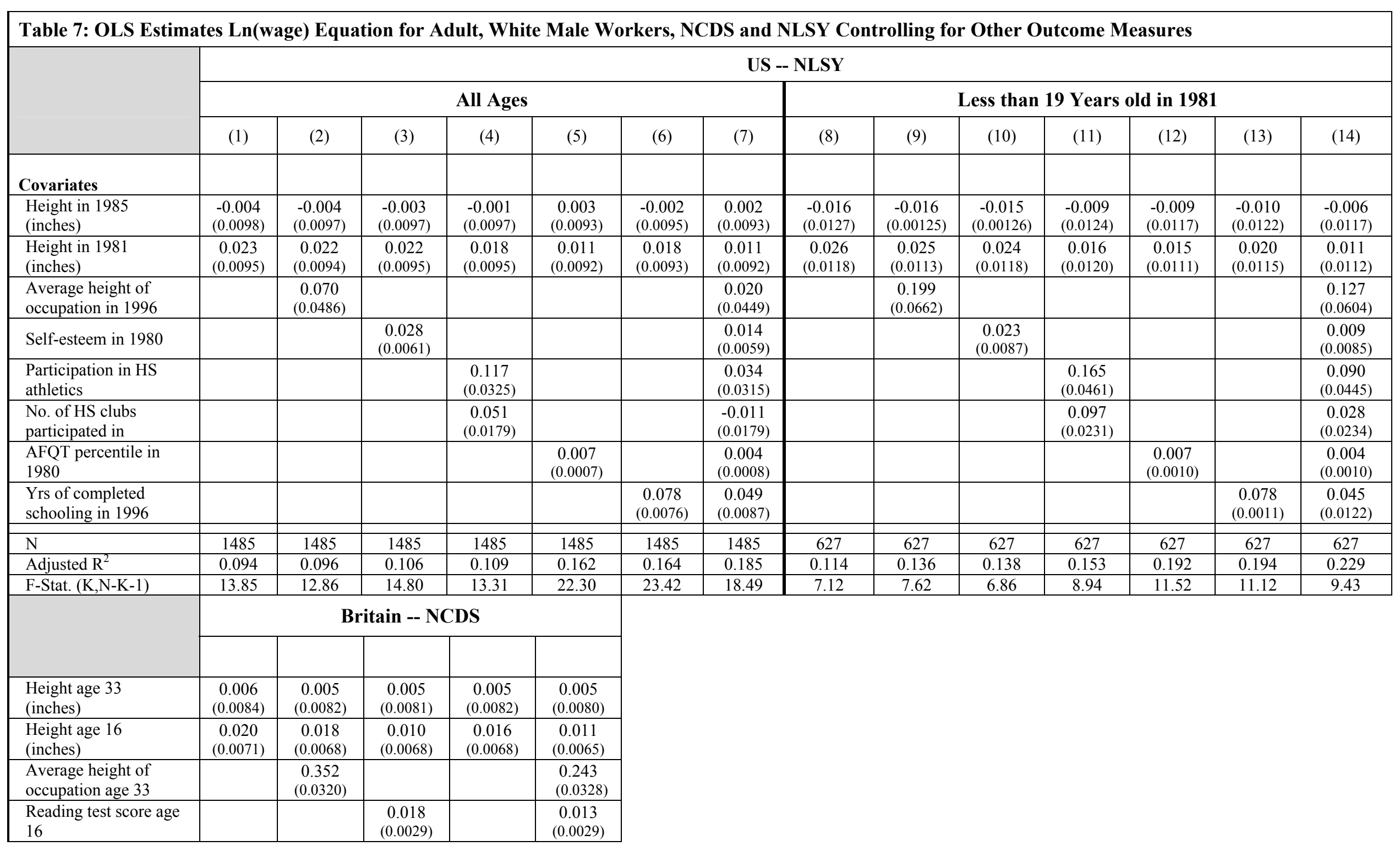




\begin{tabular}{|l|c|c|c|c|c|}
\hline Math test score age 16 & & & $\begin{array}{c}0.014 \\
(0.0025)\end{array}$ & & $\begin{array}{c}0.005 \\
(0.0027)\end{array}$ \\
\hline $\begin{array}{l}\text { Yrs of completed } \\
\text { schooling age 33 }\end{array}$ & & & & $\begin{array}{c}0.179 \\
(0.0191)\end{array}$ & $\begin{array}{c}0.084 \\
(0.0241)\end{array}$ \\
\hline $\mathrm{N}$ & 1376 & 1376 & 1376 & 1376 & 1376 \\
\hline Adjusted R & 0.045 & 0.125 & 0.123 & 0.109 & 0.172 \\
\hline F-Stat. (K,N-K-1) & 8.56 & 18.96 & 13.46 & 13.76 & 22.64 \\
\hline
\end{tabular}

Standard errors robust to heteroskedasticity are in parentheses.

Notes: Sample consists only of full time workers. Equations include controls for region and a constant term, and in the US age, results omitted. Average height of occupation is defined as the sample average teen height of all the workers in the respondent's occupational category, excluding the respondent himself. Occupations are divided into 17 categories in the UK and 12 in the US. In the UK, years of completed schooling are defined as the age at which the respondent left school minus five. See notes for Tables 2 and 3. 


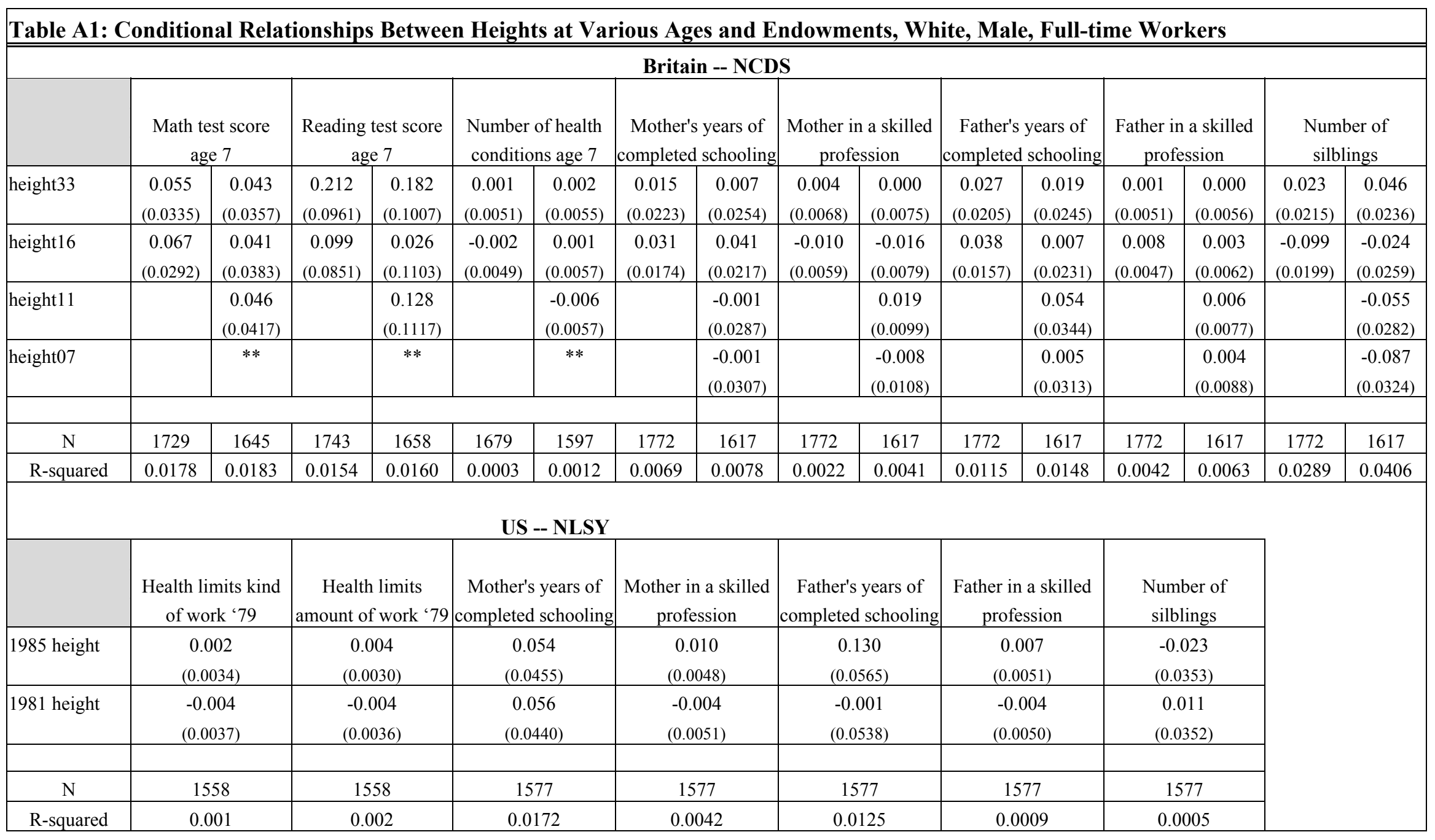

Standard errors robust to heteroskedasticity are in parentheses. In addition, each specification controls only for a constant term, results omitted. 